\title{
Profile of infected pregnant women and children exposed to HIV at a specialized service in the South of Brazil
}

\author{
Marília Alessandra Bick 1 \\ Tamiris Ferreira 2 \\ Clécia de Oliveira Sampaio 3 \\ Stela Maris de Mello Padoin 4 \\ Cristiane Cardoso de Paula 5
}

1-5 Programa de Pós-Graduação em Enfermagem. Departamento de Enfermagem. Centro de Ciências da Saúde. Universidade Federal de Santa Maria. Av. Roraima, $n^{\circ}$ 1000. Prédio 26, $3^{\circ}$ andar, sala 1336. Bairro Camobi. Santa Maria, RS, Brasil. CEP: 97.105-900. E-mail: cris_depaula1@hotmail.com

\begin{abstract}
Objectives: to characterize the social and clinical profile of pregnant women infected with HIV, the factors associated to the prevention of vertical transmission, and to analyze the quality of the information available in the SINAN notification forms and clinical records of infected pregnant women and children exposed to HIV in a specialized service in the countryside of Rio Grande do Sul.

Methods: retrospective documentary study conducted from medical records of $110 \mathrm{HIV}$ mothers and their children born between June/2014 and March/2017. For the analysis, the absolute frequency and the data percentage were taken under consideration.

Results: the characterization of infected women represents a Brazilian scenario among young adults, low schooling level and the occurrence of unpaid employment situation. Most mothers underwent treatment during pregnancy and had prenatal care with the intention of applying the prophylactic measures recommended by the national protocols. A greater occurrence of incompleteness of data in the factors of prevention of vertical transmission was identified.

Conclusions: the compromise is identified regarding the quality of assistance addressed to the population, which is largely exposed to unfavorable social conditions. The occurrence of data incompleteness shows that there is still not a culture among health professionals that ensures that the information is adequately filled out and favors the exchange of the information among the services.
\end{abstract}

Key words HIV, Vertical transmission of infectious disease, Health information systems, Brazil 


\section{Introduction}

In Brazil, since the beginning of the outbreak in 1980 to June $2017,882,710$ cases of AIDS were notified to the Coordenação Nacional de Infecções Sexualmente Transmissiveis e Aids do Ministério da Saúde (Brazilian Health Ministry's National Coordination of Sexually Transmitted Diseases and AIDS). Among these, 576,245 occurred in males and 306,444 in females. Between 1980 and 2002 an increase in the number of cases among women was observed, which focused on the feminization process of infection by the Human Immunodeficiency Virus (HIV) in the period of 2003 to 2008 , in which for each 15 infected men there were 10 infected women. ${ }^{1}$ This process reveals the paradigm of the female nature in Brazil, regarding: inevitability of motherhood, passivity in the relationship, gender inequality and the (un)availability of preventive methods controlled by Brazilian women.2,3

In the state of Rio Grande do Sul presents since 2000, the highest rates of HIV detection in pregnant women, which in 2016 revealed a rate 2.2 times higher than the national one with 5.6 cases for each thousand children born alive. 1 The vertical exposure category derives from basically three moments: gestation, childbirth and after the birth and through breastfeeding. ${ }^{4}$ At these moments there is evidence of the effectiveness of prophylaxis, 5,6 in which Brazil is considered a world reference due to the respect in public policies for confronting the outbreak.

The control of vertical transmission represents a challenge to public policies, which are dependent on its proper information about epidemiological quality data. In Brazil the source of these data is the compulsory notification of cases of HIV/AIDS in the Sistema de Informações de Agravos e Notificação (SINAN) (Notable and Severe Diseases Information System). ${ }^{1,7}$ However, it is possible to identify the high percentage of ignored or unfilled information in clinical or on electronic records.8-10 Considering the Fichas de Notificação Individual (FIN) (Individual Notification Forms) and the data from the health information systems, there are methods applied to assess their completeness, in order to build strategies to qualify the process, correct inadequacies in the instruments besides incompleteness and inconsistency of the data, reassuring the necessity of a permanent training of the operators and analysis on technical documents referring to classify the variables, and among others. 1,11

SINAN is a system from the Ministry of Health responsibility and controlled by the Secretaria de
Vigilância à Saúde (Health Surveillance Secretary). It has as a purpose to record and process data on the diseases and notify the national territory, allowing the execution of situational diagnosis, and indicate possible risk factors and the epidemiologic situation in the country, through the publication of bulletins and yearbooks. SINAN data feed can be held at the health units as well as in health departments. ${ }^{7}$ The document on GM/MS 201 of November 3rd, 2010 is responsible for monitoring and regulating the data entry and the document on GM/MS 1,378 of July 9th, 2013 is responsible for financing the Health Surveillance actions. Thus, the filling out of the FINs must be carried out by the professionals for each user that presents any notification of occurrence in the region of interest or compulsory, which are presented by the document on GM/MS 204 of January 29th, 2007.7,12,13

The notification of HIV infection in pregnant women, parturients or puerperals and child exposed to vertical transmission risk must be carried out through FIN and sent weekly to the health secretaries through the system. In these cases, each pregnancy of women infected by HIV, a new notification of a HIV pregnancy is made. When a child is born, the FIN is filled out to inform the one exposed to HIV. For each notification a copy must be attached to the clinical record 14 which consists of a set of standardized documents, intended to register all the care information provided to the user in the hospital service. The documental study can direct the care to the professionals' practice and to the planification of health services managers, since it presents the local reality and the importance of properly filling out these instruments. 11,15 When considering HIV, the adequacy of the policies aimed for this population depends on the availability and quality of data about the characterization of families available in the services. 1,4

The exposure to social risk factors, such as poverty and clinical, in which stands out malnutrition and infectious diseases, compromises the child's development, considering that the first thousand days of life (from gestation to the second full year) are stablished as a milestone in the child's physical, cognitive, emotional and cultural evolution. 16 These factors are related to the clinical outcome of the child exposed to HIV.

It is assumed that a reliable register of epistemological data is fundamental to the investigation of the serological condition and to the arrangement of actions and prevention policies of vertical HIV transmission, which are indispensable to support and promote children's health. Therefore, the objective 
of this study was to characterize the social and clinical profile on pregnant women who are infected by HIV and the factors associated with the prevention of vertical transmission, as well as to analyze the quality of the information available in SINAN's notification forms and clinical records on infected pregnant women and children exposed to HIV in a specialized service in the countryside of Rio Grande do Sul.

\section{Methods}

A retrospective documentary study was developed in the medical file service at the Hospital Universitário de Santa Maria (HUSM) (University Hospital of Santa Maria), located in the central region in the state of Rio Grande do Sul. As inclusion criterions, all children born vertically exposed to HIV in the period between July 2014 and March 2017 were included. Tardily reported children (out of the data collection period) and pregnancies terminated in miscarriage or stillbirth were excluded.

According to the data from the Núcleo de Vigilância Epidemiológica Hospitalar (NVEH) (Hospital Epidemiologic Surveillance Center), in the predefined period for this study, 126 cases of pregnant women infected by HIV were notified at SINAN. Among these, 16 were excluded: 14 had miscarriages, one had a stillborn, and one duplicated the notification (considered only once). Therefore, the result was an eligible population of 110 children vertically exposed to HIV.

The data collection was carried out in the period between February 2016 and March 2017, through clinical records of children exposed to HIV and pregnant women infected by HIV as well as the respective notification forms to SINAN. The access to the medical records was held in the file service of HUSM, which has control (release, receipt, filing out and management of documents and test results) of the collection of approximately 370 thousand clinical records, and besides the support for documentary researches developed in the institution. This support is arranged by presential and previous solicitation of the required records with a daily limit of ten per collector. The data query room assists five people per shift, due to its physical infrastructure. The solicitation for this present research demanded a list planning of the eligible population, as well as the elaboration of a schedule for the collectors' team. The list was composed of the hospital record number and the mother's name, as well as in these same files had information about the child. Each documentary collection generated a research instrument code with common access for the whole team.

For this purpose, three Master students and three scientific initiation scholarship students formed the collection team, all members of the Cuidado à Saúde das Pessoas, Familias e Sociedade (GP-PEFAS) ( Health Care Group for People, Family and Society (GP-PEFAS) at the Universidade Federal de Santa Maria (Federal University of Santa Maria).The responsible researcher promoted previous training and supervision for the team.

The data collection instrument was developed from the investigation protocol of vertical HIV transmission cases, and included data about mother and child's social and clinical characterization, the mother's epidemiologic background, about prenatal care, delivery, childbirth and puerperium, as well as the conclusion of the investigation about the vertical HIV transmission. The instrument was inserted in the Epi Info ${ }^{\mathrm{TM}}$ program (version 7.1.0.6) for data collection in an electronic format (tablet) and, subsequently, for database development, dismissing independent double typing. The pre-test enabled the adaptation of the variables, avoided responses of bias and clarified the collectors' doubts. Moreover, the orientations were registered in the documentary collection manual from the matrix research project "Avaliação da capacidade familiar para cuidar de crianças expostas ao HIV" (CAPFAM I).(Evaluation of family capability to care for children exposed to HIV). The database was subjected for statistical analysis, which considered the absolute and percentage frequency of the data.

The project was approved by the Ethics Committee at the Universidade Federal de Santa Maria (Federal University of Santa Maria) (CAAE number: 50609615.1.0000.5346, document number 1.963.382), and was elaborated according to the Resolution 466/12 of the Conselho Nacional de Saúde (National Health Council).

\section{Results}

The social characterization of the pregnant women revealed predominance of gestations in the age range between 26 and 35 years old (51.8\%), and $2.7 \%$ of incompleteness in the medical records. The pregnant women's schooling follows the national tendency (45.5\%) with incomplete elementary schooling, expressed in the notification form from SINAN as $1^{\text {st }}$ to $4^{\text {th }}$ grades; this field presented $9.1 \%$ of data incompleteness. Regarding to their occupation, $59.4 \%$ were identified as housewives. The sexual partner was considered steady at $72.7 \%$ and $14.6 \%$ were without any partner. Additionally, the partner's 
Social characterization and data completeness on pregnant women infected by HIV ( $n=110)$. Santa Maria, RS, 2017.

\begin{tabular}{|c|c|c|c|c|}
\hline \multirow{2}{*}{ Variables } & \multirow{2}{*}{$N=110$} & \multirow{2}{*}{$\%$} & \multicolumn{2}{|c|}{ Incompleteness } \\
\hline & & & $\mathrm{n}$ & $\%$ \\
\hline Age group (years) & & & 3 & 2.7 \\
\hline $16-25$ & 35 & 31.8 & & \\
\hline $26-35$ & 57 & 51.8 & & \\
\hline $36-45$ & 15 & 13.7 & & \\
\hline Schooling & & & 10 & 9.1 \\
\hline No Schooling & 1 & 0.9 & & \\
\hline Incomplete Elementary Schooling & 50 & 45.5 & & \\
\hline Complete Primary Schooling & 3 & 2.7 & & \\
\hline Incomplete High Schooling & 11 & 10.0 & & \\
\hline Complete High Schooling & 27 & 24.5 & & \\
\hline Higher Education & 8 & 7.3 & & \\
\hline Profession & & & 9 & 8.2 \\
\hline House wife & 65 & 59.4 & & \\
\hline Student & 4 & 3.6 & & \\
\hline Technical Level & 5 & 4.5 & & \\
\hline Liberal Professional & 4 & 3.6 & & \\
\hline Industry or Trade Services & 10 & 9.0 & & \\
\hline Cleaning or Domestic Services & 13 & 11.7 & & \\
\hline City Residing & & & 1 & 0.9 \\
\hline Santa Maria & 81 & 73.7 & & \\
\hline Other Cities in the Region & 28 & 25.4 & & \\
\hline Residence Zone & & & 3 & 2.7 \\
\hline Urban & 86 & 78.2 & & \\
\hline Peri-Urban & 13 & 11.8 & & \\
\hline Rural & 8 & 7.3 & & \\
\hline Sexual Partner & & & 16 & 14.6 \\
\hline Stable Partner & 80 & 72.7 & & \\
\hline Multiple Partners & 14 & 12.7 & & \\
\hline Partner's HIV Status & & & 42 & 38.1 \\
\hline Infected & 29 & 26.4 & & \\
\hline Non-Infected & 19 & 17.3 & & \\
\hline Unknown Sorology & 20 & 18.2 & & \\
\hline
\end{tabular}

serological condition had been registered in only $61.9 \%$ of the medical records, in which $18.2 \%$ did not know about the serology. However, there was $38.1 \%$ of incompleteness of this data representing the highest incompleteness present in the social characterization of infected pregnant women (Table 1).

Table 2 presents the clinical variables of pregnant women infected by HIV. The filling out of the individual notification form was carried out in the $3^{\text {rd }}$ trimester for $61 \%$ of the pregnant women. In addition, the table reveals data incompleteness at $27.2 \%$

Regarding injectable drug use, $36.4 \%$ presented data incompleteness in clinical records, and only
$2.7 \%$ were identified as users. Data incompleteness about time of diagnosis occurred in $21.7 \%$, and regarding the ones who filled out, there was a prevalence of women with 1 to 5 years of infection $(34.5 \%)$, followed by $25.4 \%$ with less than a year of infection.

Prenatal care was not carried out by $3.6 \%$ of the pregnant women, and $13.6 \%$ found incompleteness in the medical records; among the others, $65.5 \%$ accessed the high-risk pregnancy service at HUSM. The HIV diagnosis occurred during the prenatal period for $30 \%$ of the women, $5.4 \%$ of the diagnoses were identified during delivery and $1.8 \%$ after childbirth. Most women were under pregnancy follow-up $(80 \%)$ receiving antiretroviral drugs for treatment 
Clinical characterization and data completeness on pregnant women infected by HIV ( $n=110)$. Santa Maria, RS, 2017.

\begin{tabular}{|c|c|c|c|c|}
\hline \multirow{2}{*}{ Variables } & \multirow{2}{*}{$N=110$} & \multirow{2}{*}{$\%$} & \multicolumn{2}{|c|}{ Incompleteness } \\
\hline & & & $\mathrm{n}$ & $\%$ \\
\hline Individual notification of the pregnant woman & & & 25 & 27.2 \\
\hline First Trimester & 5 & 4.5 & & \\
\hline Second Trimester & 8 & 7.3 & & \\
\hline Third Trimester & 67 & 61.0 & & \\
\hline Use of injectable drugs & & & 40 & 36.4 \\
\hline Yes & 3 & 2.7 & & \\
\hline No & 67 & 60.9 & & \\
\hline Time of diagnostic (years) & & & 24 & 21.7 \\
\hline$<1$ & 28 & 25.4 & & \\
\hline $1-5$ & 38 & 34.5 & & \\
\hline $6-10$ & 11 & 10.0 & & \\
\hline 11 years or more & 13 & 12.0 & & \\
\hline Prenatal Care & & & 15 & 13.6 \\
\hline Specialized Service & 72 & 65.6 & & \\
\hline Primary Care & 16 & 14.5 & & \\
\hline Private Service & 3 & 2.7 & & \\
\hline When was the diagnosis carried out on HIV infection & & & 3 & 2.7 \\
\hline Before Prenatal & 66 & 60.1 & & \\
\hline At Prenatal Care & 33 & 30.0 & & \\
\hline At the Parturition & 6 & 5.4 & & \\
\hline Puerperium & 2 & 1.8 & & \\
\hline Use of antiretrovirals for treatment during pregnancy & & & 7 & 6.4 \\
\hline Yes & 88 & 80.0 & & \\
\hline No & 15 & 13.6 & & \\
\hline Viral Load & & & 32 & 29.1 \\
\hline Undetectable & 36 & 32.7 & & \\
\hline Detectable & 42 & 38.2 & & \\
\hline Clinical Complications & & & 69 & 62.9 \\
\hline Metabolic Alterations & 4 & 3.6 & & \\
\hline Urinary Infection & 5 & 4.5 & & \\
\hline Vaginal Infection & 7 & 6.4 & & \\
\hline Psychological Alterations & 4 & 3.6 & & \\
\hline Respiratory Problems & 6 & 5.4 & & \\
\hline Reaction to Antiretrovirals & 2 & 1.8 & & \\
\hline Use of Alcohol or Drugs & 13 & 11.8 & & \\
\hline Coinfections & & & 81 & 73.7 \\
\hline Hepatitis C & 5 & 4.5 & & \\
\hline Human Papilloma Virus & 3 & 2.7 & & \\
\hline Syphilis & 20 & 18.2 & & \\
\hline Tuberculosis & 1 & 0.9 & & \\
\hline Obstetric Complications & & & 79 & 72.0 \\
\hline Threatened Miscarriage & 6 & 5.4 & & \\
\hline Intrauterine Growth Restriction & 5 & 4.5 & & \\
\hline Gestational Diabetes & 6 & 5.4 & & \\
\hline Hypertension & 8 & 7.3 & & \\
\hline Preterm Birth & 6 & 5.4 & & \\
\hline
\end{tabular}


and prevention of vertical transmission. In this field, there was $6.4 \%$ of incompleteness. The maternal viral load closer to the date of the delivery was detectable in $38.2 \%$ of the pregnant women, and presented incompleteness of $29.1 \%$. The absence of viral load counting or filling in the data in the medical records can hamper the investigation of the vertical HIV transmission cases, considering that the duration of the undetectable viral load is a protective factor to vertical transmission.

On the other hand, clinical intercurrences, obstetric complications and coinfections can disrupt the prevention of vertical transmission. It was found that higher incidence of alcohol and drug use was $11.8 \%$ with $62.9 \%$ of incompleteness, $7.3 \%$ had arterial hypertension with $73.3 \%$ of incompleteness and $18.2 \%$ for syphilis with $72 \%$ of incompleteness, respectively. The coinfections were the data of pregnant women clinical characterization which presented the highest incompleteness, with $73.7 \%$ of missing data.
The factors related to childbirth, associated to prevention of vertical transmission, are displayed in Table 3. The delivery method was elective cesarean section for most pregnant women (66.4\%). Membrane rupture occurred for $17.3 \%$ of the pregnant women with $14.5 \%$ of incompleteness. Among the analyzed medical records, there was $10 \%$ of incompleteness about episiotomy; however, this practice was still common in $9.1 \%$ of the deliveries. Only $80 \%$ of the medical records presented antiretroviral use for prophylaxis during delivery, with $10 \%$ of incompleteness. The use of pharmacological lactation suppression had been registered in $82.7 \%$ of the medical records, but $14.5 \%$ of data incompleteness occurred. Regarding the execution of the anti-HIV quick test in moments near delivery, $46.4 \%$ of incompleteness was found; apart from that, considering the clinical records in which there was information, the testing had not been executed for $28.2 \%$ of the pregnant women.

Table 3

Factors associated to prevent vertical transmission of HIV at birth and data incompleteness $(n=110)$. Santa Maria, RS, 2017.

\begin{tabular}{|c|c|c|c|c|}
\hline \multirow{2}{*}{ Variables } & \multirow{2}{*}{$N=110$} & \multirow{2}{*}{$\%$} & \multicolumn{2}{|c|}{ Incompleteness } \\
\hline & & & $\mathrm{n}$ & $\%$ \\
\hline Type of Delivery & & & 4 & 3.6 \\
\hline Vaginal & 26 & 23.6 & & \\
\hline Elective Cesarean Section & 73 & 66.4 & & \\
\hline Emergency Cesarean Section & 7 & 6.4 & & \\
\hline Membrane Rupture & & & 16 & 14.5 \\
\hline Yes & 19 & 17.3 & & \\
\hline No & 75 & 68.2 & & \\
\hline Episiotomy & & & 11 & 10.0 \\
\hline Yes & 10 & 9.1 & & \\
\hline No & 88 & 80.9 & & \\
\hline Use of Antiretrovirals Before Delivery & & & 11 & 10.0 \\
\hline Yes & 88 & 80.0 & & \\
\hline No & 10 & 9.1 & & \\
\hline Use of Lactation Inhibitor & & & 16 & 14.5 \\
\hline Yes & 91 & 82.7 & & \\
\hline No & 3 & 2.8 & & \\
\hline Quick Test Before Delivery & & & 51 & 46.4 \\
\hline Positive / Reagent & 21 & 19.1 & & \\
\hline Negative / No Reagent & 5 & 4.5 & & \\
\hline Unperformed & 31 & 28.2 & & \\
\hline Undetectable & 2 & 1.8 & & \\
\hline
\end{tabular}


Factors associated to prevent vertical HIV transmission to children exposed to HIV and data incompleteness $(n=110)$. Santa Maria, 2017.

\begin{tabular}{|c|c|c|c|c|}
\hline \multirow{2}{*}{ Variables } & \multirow{2}{*}{$\mathrm{N}=110$} & \multirow{2}{*}{$\%$} & \multicolumn{2}{|c|}{ Incompleteness } \\
\hline & & & $\mathrm{n}$ & $\%$ \\
\hline Early oral prophylaxis for the children & & & 11 & 10.0 \\
\hline Yes & 98 & 89.1 & & \\
\hline No & 1 & 0.9 & & \\
\hline How many hours of life began the oral prophylaxis? & & & 20 & 18.2 \\
\hline$<1$ hour & 3 & 2.7 & & \\
\hline 1 to 2 hours & 36 & 32.7 & & \\
\hline 2 to 4 hours & 42 & 38.2 & & \\
\hline$>4$ hours & 9 & 8.2 & & \\
\hline Received breastfeeding & & & 8 & 7.3 \\
\hline Yes & 5 & 4.5 & & \\
\hline No & 97 & 88.2 & & \\
\hline Received cross nursing & & & 17 & 15.5 \\
\hline Yes & 1 & 0.9 & & \\
\hline No & 92 & 83.6 & & \\
\hline Time of antiretroviral use in the child (weeks) & & & 21 & 19.1 \\
\hline $3-5$ & 78 & 70.9 & & \\
\hline 6 & 11 & 10.0 & & \\
\hline 1st viral load test in the child & & & 33 & 30.0 \\
\hline Detectable & 3 & 2.7 & & \\
\hline Inconclusive & 2 & 1.8 & & \\
\hline Undetectable & 61 & 55.4 & & \\
\hline Negative / No Reagent & 1 & 0.9 & & \\
\hline Positive / Reagent & 10 & 9.1 & & \\
\hline $2^{\text {nd }}$ viral load test in the child & & & 39 & 35.5 \\
\hline Detectable & 2 & 1.8 & & \\
\hline Undetectable & 58 & 52.7 & & \\
\hline Positive / Reagent & 1 & 0.9 & & \\
\hline Case Evolution & & & 94 & 85.4 \\
\hline Infected & 3 & 2.7 & & \\
\hline Uninfected & 11 & 10.0 & & \\
\hline Loss at Follow-Up & 2 & 1.8 & & \\
\hline
\end{tabular}

Regarding to the factors related to the child and that are associated to vertical HIV transmission, oral prophylaxis had occurred in $89.1 \%$ of the cases. The time of ingestion after the birth was of 2 to 4 hours for $38.2 \%$, less than 1 hour of life $2.7 \%$, and $18.2 \%$ of the medical records was data incompleteness. The register of breastfeeding was of $4.5 \%$ and crossnursing $0.9 \%$; nonetheless, the data incompleteness presented $7.3 \%$ and $15.5 \%$, respectively.

The total time of antiretroviral use in children from 3 to 5 weeks old prevailed to $70.9 \%$, however, with $19.7 \%$ of incompleteness. The results of the first tests to confirm the serological condition were undetectable for $55.4 \%$ of the children, in addition to $30 \%$ of medical records with incomplete quantification of the viral load. The second viral load revealed $1.8 \%$ of the children with detectable results and $0.9 \%$ positive/reagent, but with high occurrence of data incompleteness of $35.5 \%$. The evolution of the case was the variable with the highest occurrence of incompleteness, $85.4 \%$; regarding to the other children, $10 \%$ were considered non-infected, $2.7 \%$ received HIV diagnosis and $1.8 \%$ lost continuity in this outpatient care clinic. These data are displayed on Table 4. 


\section{Discussion}

The maternal characterization reflects in data from other national studies, in which the age range of most infected pregnant women corresponds to the peak of the reproductive period. $6,10,17$ Since 2000, the highest occurrence in notifications from SINAN corresponds to pregnant women aged between 20 to 24 years. ${ }^{1}$

The schooling levels also follow the national tendency with predominance of women with incomplete primary schooling. This lower level of schooling is indicative for the poor access of information in preventing vertical transmission. In addition to that, the occurrence of unpaid occupation is equivalent to studies that present the issue of pregnant women with HIV social situation.3,17,18 Nonetheless, a pregnant woman's social networking appears to be strengthened by the presence of a stable partner, since studies present a partner as a contributor of the adherence to recommend prophylaxis for vertical transmission. 19,20

In the clinical characterization, the data incompleteness was hardly prevalent, which can be attributed to the greater incidence of registrations in the women's consultations during pregnancy. Regarding to the evaluation of HIV prevention actions during prenatal care, apart from a high occurrence of data incompleteness, the notification in the third trimester of gestation prevailed, which may represent the loss of a moment to avoid vertical transmission, due to noncompliance with the recommendations about the anti-HIV testing that should be carried out in the first and third trimesters. 4

The high incidence of incompleteness in the registrations related to the factors of intercurrences, coinfections and obstetric complications problematizes the relation of fragmented care, which does not consider the existent correlations between these and the decrease in effectiveness of the compliance to measure and prevent vertical transmission. Syphilis was the main coinfection registered, and is pointed out as one of the most recurrent in the country; additionally, when these two infections occur together, the vertical transmission of HIV is more likely to occur. Thus, the performance of quick tests in all pregnant women is necessary to ensure health and reduce maternal and infant mortality. 1,21

In this study, the precaution with their own health is confirmed, because women present greater adherence to treatment, consider it easy to maintain it, do not present health problems, and avoid alcohol consumption. The consumption of alcohol and drugs is also mentioned in the literature as a reducing aspect of adherence to antiretroviral therapy (ART), which enables the increase of viral load.22,23 Despite the maintenance of clinical follow-up and of ART, the data show that most of the pregnant women had a detectable viral load, in other words, an increase in the risk factor for vertical HIV transmission. A study also carried out in the south of Brazil, that analyzed the prevalence and factors associated with vertical HIV transmission, corroborates these results and points out the failure of antiretroviral therapy and the high maternal viral load as the main risk factors for the vertical transmission of the virus. ${ }^{24}$

The literature points out the existent relation between attendance to prenatal consultations and improvement of adherence to antiretroviral therapy. 6 Consequently, the adherence to prophylaxis of vertical transmission also depends on the strategies that integrate prenatal care with specialized service, enabling higher satisfaction and safety of the women towards professionals and health services. 25

The results found indicate a preference for prenatal care in the same service to which women are linked in HIV treatment. Furthermore, the late diagnosis made during childbirth or puerperium, only $7.2 \%$, was below the one found in another study also carried out in Brazil, with $22.2 \%$ of the cases diagnosed in the same period. 21 Inadequate access to prenatal care can contribute to the occurrence of infection in the child, resulting mainly from the low maternal adherence to antiretroviral treatment, which results in $65 \%$ of vertical transmission cases occurred during labor or delivery. 4

Regarding the factors that relate in preventing vertical transmission during childbirth, the high incidence of elective cesarean sections represents compliance with the recommendations for prophylaxis. In this case, vaginal delivery is recommended only in cases of women with undetectable viral load and appropriate adherence to antiretroviral therapy. ${ }^{7}$

Corroborating results, a study carried out in Minas Gerais State also indicates the prevalence of choosing cesarean section for delivery. 26 The time of the membrane rupture in this study was longer than 4 hours in just $6.3 \%(n=7)$ of the cases, similar to the one found in the South region of Brazil (10.8\%). The occurrence of the rupture for a period longer than 4 hours increases the possibility of vertical HIV transmission. ${ }^{26}$ Also, episiotomy, which occurs in $9.1 \%$ of the cases, increases the potential of vertical transmission of HIV, and, for this reason, cesarean section is indicated when the pregnant woman's serological condition is unknown. ${ }^{27}$

The importance of antiretroviral prophylaxis during labor is justified by the increased exposure of 
the child to the maternal blood, and the practice makes it possible to prevent up to $90 \%$ of cases of vertical transmission. ${ }^{4}$ This recommendation was followed in most cases of this study, however, a research carried out in Santa Catarina State presents a reduction in the use of the medication between prenatal care and childbirth, indicating noncompliance with the prophylaxis recommendations. ${ }^{8}$ The quick test is advised only for pregnant women who do not have a previous diagnosis of HIV and, regarding this recommendation, $28.2 \%$ of the women were not tested. However, in $46.4 \%$ of the medical records, evidence of the test was not found.

Regarding to the care for newborns, $89 \%$ of them received oral prophylaxis at birth, and $73.6 \%$ followed the ministerial recommendation, which advices oral prophylaxis in the first 4 hours after the child is born. A study indicates compliance with the prophylaxis recommendations for newborns, however, the antiretroviral treatment took place in the first 24 hours of life for $91 \%$ of the children. 6 Apart from that, the preventive effects of the use of antiretroviral drugs after the first 48 hours of the child's life are unknown. ${ }^{4}$ The incidence of incompleteness in $18.2 \%$ of the medical records represents a difficulty for professionals to comprehend the importance of keeping the patients' clinical records updated, principally, in cases of a necessity to investigate vertical exposure to HIV.

Since the child is totally dependent on a caregiver and dealing with HIV exposure transcends normal needs, joining efforts are needed from these children's caregivers, as well as from the health professionals who assist them, to ensure the prevention of vertical transmission of the virus. 28 It is known that the caregiver can only appropriately comply with all recommendations when they are aware of the real possibility of infection, and of their responsibility to ensure special and different care on the follow-up, medication prophylaxis, vaccination and nutrition. 17

With respect to feeding children exposed to HIV, in national level it is recommended to replace breastfeeding with infant formula, since this measure prevents in $30 \%$ the occurrence of infection by the virus. In addition, the practice of cross-nursing is discouraged because of the lack of knowledge of the serological condition of the woman who will perform it. 4 A study carried out in Fortaleza, Ceará State responds to the ministerial recommendations, and indicates the non-occurrence of offering human milk to children who are vertically exposed to HIV. 17 In contrast, the present study revealed the occurrence of some cases on breastfeeding and cross-nursing, as well as incompleteness in the records about this information.

In the present study, $70.9 \%$ of the cases followed the ministerial recommendation of drug prophylaxis for the child, which advises the administration of ARV for a minimum period of four weeks. However, a high incidence of incomplete data was found in the medical records. It is important to emphasize here the increase in the potential of the antiretroviral prophylaxis protection factor for the newborn when it is conducted according to this recommendation. ${ }^{4}$

Furthermore, monitoring the exposed child until confirmation of their diagnosis must be a priority on the epidemiological surveillance. However, the occurrence of loss of follow-ups, which damages the closure of the case, is quite high, as shown in a study carried out in Porto Alegre City. 21 This discontinuation in outpatient follow-up might be related to a higher incidence of data incompleteness in clinical records associated to laboratory investigation of exposed children.

Quantification of viral load 1 and 2 was not registered in $30 \%$ and $35.5 \%$ of the clinical records, respectively. Additionally, the evolution of the child's case, that is, the closure of the serological investigation of the child, is absent in $85.4 \%$ of the medical records. On the other hand, a study also carried out in Rio Grande do Sul State revealed a percentage of more than $70 \%$ of closure of the child's serological investigation and only $17.2 \%$ of the cases recorded a loss in the follow-ups, which do not have enough data. 29 The absent data represents a concern factor for the health services, since the condition of infecting or not these children is unknown. The implementation of monitoring the exposed children along with active search for the losses of outpatient follow-up, in order to monitor the reliable occurrence of the cases, may improve this population's health care.

The social characterization of the pregnant women infected by HIV indicates similarity to other studies carried out at a national level in Brazil with prevalence of poverty and stigmatization. The clinical characteristics revealed that pregnant women often overcome socioeconomic difficulties, in order to ensure the protection of their children. From the data analysis, it was possible to identify that the completeness of information regarding to pregnant women presents a satisfactory outcome with low incidence of unfilled information. However, the follow-up care for the child exposed as well as the outcome of the diagnosis on infection due to the exposure of maternal HIV, indicates low quality in the filling out of medical records. 
It should be emphasized that the data are not exclusive from the forms at SINAN, since most of them presented unsatisfactory completeness with absence of necessary information to evaluate the application of prophylactic measures on vertical transmission; thus, the forms available in the clinical records of the service were also considered. This factor points to the considerable number of underreported data and the lack of communication between the health systems and services. The effectiveness of Brazilian policies for HIV prevention entirely depends on the data completeness on the investi-

\section{References}

1. Brasil. Ministério da Saúde. Secretaria de Vigilância em Saúde. Departamento de DST, Aids e Hepatites Virais. Bol Epidemiol HIV Aids. Brasilia, DF; 2017.

2. Costa R, Silva RRA. Factors related to feminization of the epidemy of aids: an informational study. Rev Enferm UFPE. 2013; 7 (8): 5340-44.

3. Villela WV, Barbosa RM. Trajetórias de mulheres vivendo com HIV/aids no Brasil. Avanços e permanências da resposta à epidemia. Ciênc Saúde Coletiva. 2017; 22 (1): $87-96$

4. Brasil. Ministério da Saúde. Secretaria de Vigilância em Saúde. Departamento de DST, Aids e Hepatites Virais. Protocolo clínico e diretrizes terapêuticas para manejo da infecção pelo HIV em crianças e adolescentes. Brasília, DF; 2015

5. Miranda AE, Pereira GFM, Araujo MAL, Silveira MF, Tavares LL, Silva LCF, Silva SFM, Saraceni V. Avaliação da cascata de cuidado na prevenção da transmissão vertical do HIV no Brasil. Cad Saúde Pública. 2016; 32 (9): 1-10.

6. Lima ACMA, Costa CC, Teles LMR, Damasceno AKC, Oriá MOB. Avaliação epidemiológica da prevenção da transmissão vertical do HIV. Acta Paul Enferm. 2014; 27 (4): $311-8$

7. Brasil. Ministério da Saúde. Secretaria de Vigilância em Saúde. Departamento de Vigilância das Doenças Transmissíveis. Coordenação-Geral de Vigilância e Resposta às Emergências em Saúde pública. Unidade Técnica de Gestão do Sinan. Manual de Operação: SINAN Brasília, DF; 2015.

8. Ayala ALM, Moreira A, Francelino G. Características socioeconômicas e fatores associados à positividade para o HIV em gestantes de uma cidade do sul do Brasil. Rev APS. 2016; 19 (2): 210-22

9. Gloyd S, Wagenaar BH, Woelk GB, Kalibala S Opportunities and challenges in conducting secondary analysis of HIV programmes using data from routine health information systems and personal health information. J Int AIDS Soc. 2016; 19 (5 suppl. 4): 1-6.

10. Meirelles QB, Lopes AKB, Lima KC. Vigilância epidemiológica de HIV/Aids em gestantes: uma avaliação acerca da qualidade da informação disponível. Rev Panam Salud Publica. 2016; 40 (6): 427-34. gated cases. Therefore, it is necessary to alert health professionals of the relevance of their performance in preventing vertical HIV transmission, which will improve the quality of the population's health.

\section{Acknowledgments}

This study was financed in part by the CAPES, CNPQ and FAPERGS.

11. Correia LOS, Padilha BM, Vasconcelos SML. Métodos para avaliar a completitude dos dados dos sistemas de informação em saúde do Brasil: uma revisão sistemática. Cienc Saúde Coletiva. 2014; 19 (11): 4467-78.

12. Caetano R. Sistema de Informação de Agravos de Notificação. In: Brasil. Ministério da Saúde. A experiência brasileira em sistemas de informações em saúde: Falando sobre os sistemas de informação sobre saúde no Brasil. Fundação Oswaldo Cruz. Brasília, DF; 2009.

13. Laguardia J, Domingues CMA, Carvalho C, Lauerman CR, Macário E, Glatt R. Sistema de informação de agravos de notificação em saúde (Sinan): desafios no desenvolvimento de um sistema de informação em saúde. Epidemiol Serv Saude. 2004; 13 (3): 135-46

14. Domingues RM, Szwarcwald CL, Souza PRJ, Leal MC. Prenatal testing and prevalence of HIV infection during pregnancy: data from the "Birth in Brazil" study, a national hospital-based study. BMC Infect Dis. 2015; 15 (100): 111

15. Maia ABB, Barbosa AB, Silva MNP, Branco LMGC, Rodrigues LMC, Melo TMTC. Compilação técnico-científica acerca da auditoria e gestão de qualidade: revisão integrativa. Rev Enferm UFPE. 2017; 11 (Supl. 3): 1489-94.

16. Cunha AJLA, Leite AJM, Almeida IS. The pediatrician's role in the first thousand days of the child: the pursuit of healthy nutrition and development. J Pediatr. 2015; 91 (6 Suppl. 1): 44-51.

17. Freitas JG, Cunha GH, Lemos LA, Barroso LMM, Galvão MTG. Alimentação de crianças nascidas expostas ao vírus da Imunodeficiência humana. Texto Contexto Enferm. 2014; 23(3): 617-25.

18. Galvão MTG, Cunha GH, Lima ICV. Mulheres que geram filhos expostos ao virus da imunodeficiência humana: representações sociais da maternidade. Rev Eletr Enf. 2014; 16 (4): 804-11.

19. Langendorf TF, Padoin SMM, Paula CC, Souza IEO, Aldrighi JD. Profilaxia da transmissão vertical do HIV: cuidado e adesão desvelados por casais. Rev Bras Enferm. 2016; 69 (2): 275-81.

20. Pacheco BP, Gomes GC, Xavier DM, Nobre, CMG, Aquino DR. Dificuldades e facilidades da família para cuidar a criança com HIV/Aids. Esc Anna Nery. 2016; 20 (2): 37883 . 
21. Acosta LMW, Gonçalves TR, Barcellos NT. Coinfecção HIV/sífilis na gestação e transmissão vertical do HIV: um estudo a partir de dados da vigilância epidemiológica. Rev Panam Salud Publica. 2016; 40 (6): 435-42.

22. Melo VH, Botelho APM, Maia MMM, Correa JMD, Pinto JA. Uso de drogas ilícitas por gestantes infectadas pelo HIV. Rev Bras Ginecol Obstet. 2014; 36 (12): 555-61.

23. Rego SEM, Rego DMS. Associação entre uso de álcool em indivíduos com AIDS e adesão ao tratamento antirretroviral: uma revisão da literatura. J Bras Psiquiatr. 2010; 59 (1): 70-73.

24. Rosa MC, Lobato RC, Gonçalves CV, Silva NMO, Barra MFM, Martinez AMB, Hora VP. Avaliação dos fatores associados à transmissão vertical de HIV-1. J Pediatr. 2015; 91 (6): 523-8

25. Kleinubing RE, Paula CC, Padoin SMM, Silva CB, Ferreira $\mathrm{T}$, Cherubim DO. Estratégias de cuidador à saúde de gestantes vivendo com HIV: Revisão integrativa. Ciencia y Enfermeria. 2016; 22 (2): 63-90.

Received on August 23, 2017

Final version presented on May 28, 2018

Approved on September 20, 2018
26. Souza CP, Piantino CB, Queiroz CA, Maia MAC, Fortuna $\mathrm{CM}$, Andrade RD. Incidência de transmissão vertical do HIV entre gestantes soropositivas cadastradas em um serviço de referência regional. J Res Fundam Care. 2016; 8 (2): 4526-37

27. Kakehasi FM, Ferreira FGF, Pinto JA, Carneiro SA. Vírus da imunodeficiência humana adquirida/HIV no período neonatal. Rev Med Minas Gerais. 2014; 24 (2): 241-47.

28. Padoin SMM, Paula CC. Programa aids, educação e cidadania: perspectivas para a $2^{\mathrm{a}}$ década de extensão. Rev Saúde. 2012; 1 (38): 51-62.

29. Torres SR, Luz AMH. Gestante HIV+ e crianças expostas: estudo epidemiológico da notificação compulsória. Rev Gaúcha Enferm. 2007; 28 (4): 505-11. 